\title{
USA begynder et nyt kapitel
}

\section{Michael Ehrenreich}

\section{Det vil kunne mærkes, at USA får en ny præsi- dent. Men ikke mindst i udlandet er det nødven- digt, at vi får et realistisk forhold til Barack Oba- mas kommende præsidentskab. Ellers kan den skuffelse, der nok kommer under alle omstændig- heder, blive til regulær forbitrelse}

Indsættelsen af Barack Obama som USA's næste præsident den 20. januar bliver en ganske særlig begivenhed. Historiens vingesus vil blæse ned ad Washingtons hovedstrøg Pennsylvania Avenue og vil også kunne mærkes i resten af verden. Det bliver en dag, man vil huske.

Obama-valgsejrens skelsættende natur er efterhånden blevet analyseret så mange gange, at det er vanskeligt at finde nye vinkler. Men i virkeligheden kan forløbet bedst sammenfattes i de formuleringer, som sejrherren selv brugte på valgnatten, da resultatet var i hus:

"Forandringen er kommet til Amerika”, erklærede han. "Hvis der stadig er nogle, der tvivler på, at Amerika er et sted, hvor alt er muligt, som spekulerer på, hvorvidt vores grundlovsfædres drøm endnu er i live, og som stiller spørgsmålstegn ved kraften i vores demokrati, så har de fået svaret i aften”.

Demokraten Barack Obamas sejr markerer begyndelsen på et nyt betydningsfuldt kapitel i USA's politiske udvikling. Men det vil være forkert at betragte den som en revolution. Bevæger man sig op i dette luftlag, vil det både trivialisere mandens bedrift og rejse helt urealistiske forventninger til hans kommende præsidentskab.

Valgsejren skyldes hovedsageligt to forhold. For det første hovedpersonens helt ekstraordinære lederevner og personlighed. Hans karisma og evne til at få folk med sig repræsenterer egenskaber på et niveau, man ikke har set i amerikansk politik i et halvt århundrede.

For det andet den siddende præsi- 
dents næsten ligeså ekstraordinære mangel på opbakning. Tilslutningen til George W. Bush er den laveste, siden Gallup-instituttet begyndte at lave opinionsmålinger. Kombineres dette med USA's deltagelse i to krige og en økonomisk krise, der nåede sin foreløbige kulmination i ugerne op til valgdagen 4 . november, giver det næsten sig selv, at den republikanske kandidat John McCain ikke havde mange chancer.

Faktisk var det noget af en overraskelse, at McCain trods alt fik 46 procent af stemmerne. Et meget stort mindretal af de amerikanske vælgere var altså ikke rede til at binde an med den kun 47-årige senator fra Illinois - selv i lyset af USA's økonomiske problemer og landets pressede internationale situation.

Analyserer man valgresultatet på basis af antallet af valgmænd, tegner der sig et lignende billede. Som det fremgår af tabellen, blev Obamas sejr ganske vist større, end vi har set ved valgene siden årtusindskiftet. Men den nåede ikke samme højder som Ronald Reagans sejre i 1980'erne. Den blev snarere på et niveau som Bill Clintons i 1990'erne. Det vil sige, at sejren i 2008 blev stor, men uden at være prangende.

\section{Obamas mandat}

Tallene betyder, at Obama overtager præsidentembedet på basis af et klart folkeligt mandat. Men tilhængere af det demokratiske parti, sær-
Fordelingen af valgmand mellem

sejrherre og taber 1980-2008

$\begin{array}{lll}1980 & \text { Reagan 489 } & \text { Carter 49 } \\ 1984 & \text { Reagan 525 } & \text { Mondale 13 } \\ 1988 & \text { Bush 427 } & \text { Dukakis 111 } \\ 1992 & \text { Clinton 370 } & \text { Bush 168 } \\ 1996 & \text { Clinton 379 } & \text { Dole 159 } \\ 2000 & \text { Bush 271 } & \text { Gore 267 } \\ 2004 & \text { Bush 286 } & \text { Kerry 252 } \\ 2008 & \text { Obama 365 } & \text { McCain 173 }\end{array}$

ligt på venstrefløjen, der nu drømmer om et ideologisk nybrud, overfortolker valgresultatet. Flertallet af de amerikanske vælgere betragter sig - som det også fremgår af gentagne meningsmålinger - stadigt som konservative. Valgresultatet var først og fremmest et opgør med republikaneren Bush og ikke med kernen i partiets ideologi.

Amerikanerne ønsker forandring og fornyelse. De ønsker en ny stil i politik. Og de har sagt ja til en indenrigspolitisk reformpolitik, blandt andet på det forkætrede sygesikringsområde. Men de ønsker ikke det amerikanske samfund lavet om i grundlæggende forstand.

At Obama forstår denne sammenhæng, viste han allerede under valgkampen, hvor hans centrale budskaber var præget af forsoning, pragmatisme og moderation. Og han har efterfølgende vist det med sine vigtigste udnævnelser af ministre $i$ kabinettet og af særlige rådgivere $\mathrm{i}$ inderkredsen i Det Hvide Hus.

Som listen over kommende mini- 
stre og toprådgivere forelå før jul, var der langt mellem ideologerne. Hovedparten er valgt på grundlag af deres erfaring og kompetence og evne til at skabe resultater.

Det gælder ikke mindst Obamas økonomiske hold. Den kommende finansminister Timothy Geithner har årelang erfaring med at håndtere finanskriser, og som chef for centralbanken i delstaten New York har han været dybt involveret i at tackle den nuværende krise. Noget lignende gælder den kommende præsidents økonomiske rådgiver, Lawrence Summers.

Det udenrigspolitiske hold har samme præg. Hillary Clinton viste sig under primærvalgkampen som en udenrigspolitisk pragmatiker. Den kommende nationale sikkerhedsrådgiver James L. Jones nyder bred respekt blandt såvel demokrater som republikanere, og det samme kan siges om forsvarsminister Robert Gates.

\section{Bill Clintons fejl}

Listen over ministre og toprådgivere repræsenterer den endelige bekræftelse på, hvad Obamas nærmeste medarbejdere har ladet forstå i månedsvis, nemlig at de er meget opmærksomme på den forrige demokratiske præsident Bill Clintons fejltagelser i begyndelsen af embedsperioden - og ikke ønsker at gentage dem.

Clinton overfortolkede sin første valgsejr i 1992 og iværksatte en radikal reformpolitik, der ikke mindst kom til udtryk med hustruen Hillary Clintons banebrydende forslag til ændring af sygesikringen. Men reformkursen slog fejl, og regningen kom to år senere, da republikanerne vandt en overvældende sejr ved midtvejsvalgene til Kongressen. Demokraterne mistede bl.a. flertallet $\mathrm{i}$ Repræsentanternes Hus for første gang i en generation. Clinton overlevede kun som præsident ved valget i 1996 ved at gå på strandhugst blandt republikanske mærkesager.

Ikke mindst i udlandet er det afgørende, at vi forstår begrænsningerne i den kommende præsidents muligheder. Efter de markante november-dage, hvor hele verden sang med på refrænet "Change - yes, we can”, er det nødvendigt, at vi får et mere realistisk forhold til personen og politikeren Barack Obama. Ellers kan den skuffelse, der nok vil indfinde sig under alle omstændigheder, ende i regulær forbitrelse.

\section{Knaster vil bestå}

Følger man debatten i Europa i disse uger, er det tydeligt, at mange forestiller sig, at det ved skæbnens gunst er lykkedes at placere en europæisk indstillet politiker i Det Hvide Hus. De pågældende ser frem til en slags 'europæisering' af USA og af amerikansk politik. Men de vil blive slemt skuffede. For andre vil det komme som et chok, at Obama i 


\section{MICHAEL EHRENREICH}

sine kommende udspil til løsning af internationale problemer ikke vil optræde som goodwill-ambassadør for den vestlige verden men slet og ret som USA's præsident.

Vi er nødt til at komme på det rene med to ting: Dels, at Obama først og fremmest vil kæmpe for varetagelsen af USA's interesser. $\mathrm{Og}$ dels, at USA's grundlæggende udenrigspolitiske interesser ikke skifter, selvom præsidenten gør det.

For Europa betyder det, at en række knaster i det transatlantiske forhold formentlig vil bestå, også efter præsidentskiftet, selvom Obama lægger op til politiske kursændringer på de pågældende områder. Tre eksempler skal nævnes her:

I forhold til krigen i Afghanistan lægger den kommende præsident op til en forstærkning af krigsindsatsen. Men han har gjort det klart, at USA ikke længere vil gøre så stor en del af det farlige arbejde, og at han forventer et stærkere europæisk militært engagement. Det vil bl.a. resultere i et pres mod Tyskland, netop som EU's største land går ind i et valgår. Det kan således hurtigt komme til at slå gnister mellem Washington og Berlin - byen, hvor Obama i parentes bemærket under valgkampen blev hyldet som en anden rockstjerne.

Også på handelsområdet kan der komme kurrer på tråden, i dette tilfælde mellem Washington og Bruxelles. Obama var under valgkampen kritisk mod frihandel som prin- cip, og han kom betænkeligt nær ved at forlange indgåede, internationale handelsaftaler genåbnet. Så vidt kommer det næppe. Men forlanger hans demokratiske allierede $\mathrm{i}$ Kongressen, at han lever op til løfterne om at beskytte amerikanske arbejdspladser under globaliseringen, kan han få svært ved at modstå presset uden at foretage sig noget for at imødekomme protektionisterne i sit eget parti.

I Irak vil Obama indlede den gradvise amerikanske troppetilbagetrækning, som var et af hans centrale valgløfter, selvom tidsplanen næppe bliver så stram, som mange amerikanere forestiller sig. Tempoet vil helt afhænge af omstændighederne undervejs. Men der skal ikke megen fantasi til at forestille sig, at USA vil stille krav til europæerne om at betale en større del af de penge, der skal gå til at stabilisere det krigshærgede land.

\section{Verdens leder}

I en global sammenhæng er det også vigtigt at minde om, at USA's egen selvforståelse som verdens naturlige leder vil stå uantastet efter magtskiftet i Washington. Forestillingen om, at hvad der er i USA's og det amerikanske folks interesse, grundlæggende også er i resten af verdens interesse, vil leve videre under Obama. Denne forestilling er en af grundpillerne under landets internationale magtposition, men den 
vil blive forvaltet på en anden måde, end vi har set tidligere, specielt under præsident Bush.

Kernen i Obamas udenrigspolitiske filosofi er, at USA ganske vist er klodens eneste tilbageværende supermagt, men at verden alt andet lige ikke længere kan betragtes som unipolær. Det betyder, at de store trusler, som verden står overfor - fra terrorisme og slyngelstater til atomvåbenoprustning og klimaforandringer - ikke længere kan imødegås af USA alene eller i samarbejde med landets traditionelle venner og allierede.

Derfor - og her ligger det fundamentale brud med Bush-epoken må USA genoprette sit globale lederskab ved i højere grad at være et eksempel for resten af verden og samarbejde med en bred vifte af udenlandske regeringer. Dette vil kræve, at Washington åbner sig politisk over for omverdenen og bliver samarbejdende frem for at gå enegang $\mathrm{i}$ overensstemmelse med Bush-doktrinen om USA's ret til 'at slå først'.

Det bliver Hillary Clintons hovedopgave som udenrigsminister at være eksponent for denne nye åbenhed, og det er hovedforklaringen på, at Obama valgte hende til posten. Ud over et indenrigspolitisk hensyn om at trække sin største rival fra primærvalgkampen til sig og dermed for alvor forene det demokratiske parti, har den kommende præsident utvivlsomt haft et godt øje til hendes globale stjernestatus.
I en situation, hvor USA's internationale image har fået nogle alvorlige ridser i lakken, og hvor genoprettelsen af dette image vil være en afgørende forudsætning for at kunne udøve effektivt lederskab, er det vanskeligt at få øje på en anden lige så kvalificeret kandidat til udenrigsministerposten.

Som globetrottende tidligere førstedame og senator med speciale i udenrigs- og forsvarspolitik er Hillary Clinton allerede på fornavn med både politiske ledere og andre centrale spillere verden over. Hertil kommer, at hun er kvinde, og at hun i kraft af efternavnet kan trække på minderne om en anden og fredeligere tid - og et andet USA på den internationale scene.

\section{Den nye filosofi}

Konkret betyder den nye filosofi, at USA ikke længere vil basere sin internationale indflydelse alene på sin helt overlegne militære magt og trusler om dens anvendelse. De såkaldte 'bløde' magtmidler i form af diplomati og multilateralt samarbejde vil blive trukket længere frem, men uden at brugen af 'hård' magt vil blive udelukket, hvis alt andet glipper.

Det vil ifølge Obamas udenrigspolitiske rådgivere betyde, at USA igen vil arbejde via multilaterale organisationer. Hvor langt man vil gå her, er et åbent spørgsmål, og det vil hurtigt vise sig, om det bliver muligt 


\section{MICHAEL EHRENREICH}

at lade handling følge ord. Men der blev ved udpegningen af den kommende præsidents udenrigspolitiske hold lagt mærke til, at den nye FNambassadør Susan Rice får kabinetsrang, hvilket var ganske udelukket under Bush.

Det helt store springende punkt for Obamas præsidentskab bliver selvfølgelig den finanskrise, der siden valget er blevet til et egentligt $\varnothing$ konomisk tilbageslag af stort omfang. De økonomiske rammebetingelser er med andre ord ændret siden valgdagen, og det står hen i det uvisse, hvor meget dette vil påvirke hans politik.

Indenrigspolitisk ligger det fast, at der er blevet mindre økonomisk råderum til at udmønte en reformpolitik og gennemføre de velfærdsforbedringer, som Obama stillede i udsigt under valgkampen. USA kæmper i forvejen med et budgetunderskud af gigantiske dimensioner.

Udenrigspolitisk har han efter valget bekræftet sine forsikringer om, at USA vil spille en ledende rolle $i$ forsøget på at nå en aftale om at bekæmpe klimaforandringerne. Han har også gentaget løftet om, at supermagten skal gøres uafhængig af importeret olie i løbet af kun ti år. Begge dele bliver dyrt, og spørgsmå- let er tillige, hvorvidt den kommende præsident kan få Kongressen med sig.

Hovedsigtet med nærværende artikel har været at bringe vores opfattelse af USA's nye førstemand lidt ned på jorden. Det betyder langtfra, at artiklens forfatter ikke har blik for det paradigmeskift, som Barack Obama står for, og de muligheder, der tegner sig, såvel for USA som for resten af verden.

Særligt efter de forløbne otte år er det nærliggende at knytte store forventninger til den unge pragmatiker, der erobrede USA og undervejs tog hele verden med storm. Hans opstigning til magtens tinde understreger endnu engang amerikanernes evne til at genopfinde sig selv og give landets idealer om fremdrift og nytænkning konkret indhold. Ikke mindst i krisetider er man villig til at tænke nyt.

Men vores forhåbninger til Barack Obama må også være realistiske. Det vil være godt for både ham og for alle os andre.

Michael Ehrenreich er medredaktør på Kristeligt Dagblad og udenrigspolitisk kommentator. Han er tidligere udlandskorrespondent $i$ Washington. 